\title{
PERCEIVED ALTERNATIVES OPPORTUNITY SEBAGAI PEMODERASI PENGARUH KEPUASAN KERJA TERHADAP TURNOVER INTENTION PADA KARYAWAN CONSIGNMENT PT MATAHARI DEPARTEMENT STORE TBK. CABANG BENGKULU
}

\author{
Occy Rahmada Ningsih*1 \\ Sugeng Susetyo \\ Paulus Sulluk Kananlua ${ }^{1}$ \\ ${ }^{1}$ Jurusan Manajemen, Fakultas Ekonomi dan Bisnis, Universitas Bengkulu, Indonesia
}

\begin{abstract}
The purpose of this study is to determine the Perceived Alternatives Opportunitiy as moderating the effect of job satisfaction on turnover intention in employee consignment in PT. Matahari Departement Store Tbk Bengkulu City. This research use quantitative approach by using primary data collected by questionnaire. The sample is consignment employees at PT. Matahari Departement Store Tbk Bengkulu City for amount 169 person taken using the sencus method. The data processing technique of this study used Statistical Package For Social Science (SPSS) software version 16.0. The analysis which is used including validity test and reliability test. The results of this study; 1) job satisfaction has a negative effect on Turnover Intention. 2) Job Satisfaction and Perceived Alternatives Opportunity affect Turnover Intention. 3) Perceived Alternatives Opportunity moderate the effect of Job Satisfaction on Turnover Intention.
\end{abstract}

Keywords : Job Satisfaction; Perceived Alternatives Opportunity; Turnover Intention

\begin{abstract}
Abstrak
Tujuan dari penelitian ini adalah untuk mengetahui Perceived Alternatives Opportunitiy sebagai pemoderasi pengaruh kepuasan kerja terhadap turnover intention pada konsinyasi karyawan di PT. Matahari Departement Store Tbk Kota Bengkulu. Penelitian ini menggunakan pendekatan kuantitatif dengan menggunakan data primer yang dikumpulkan melalui kuesioner. Sampelnya adalah karyawan bagian konsinyasi di PT. Matahari Departement Store Tbk Kota Bengkulu sejumlah 169 orang yang diambil dengan metode sensus. Teknik pengolahan data penelitian ini menggunakan software Statistical Package For Social Science (SPSS) versi 16.0. Analisis yang digunakan meliputi uji validitas dan uji reliabilitas. Hasil penelitian ini; 1) Kepuasan Kerja berpengaruh negatif terhadap Turnover Intention. 2) Kepuasan Kerja dan Persepsi Peluang Alternatif mempengaruhi Turnover Intention. 3) Perceived Alternatives Opportunity memoderasi pengaruh Kepuasan Kerja terhadap Turnover Intention.
\end{abstract}

Kata Kunci: Kepuasan Kerja; Perceived Alternatives Opportunity; Turnover Intention

Article History: Received: (14-09-2020); Revised: (05-10-2020); and Published: (31-10-2020) Copyright @ 2020 Occy Rahmada Ningsih, Sugeng Susetyo, Paulus Sulluk Kananlua

how to cite this article: Ningsih, O.R., Susetyo, S., dan Kananlua, P. S. (2020). Perceived Alternatives Opportunity Sebagai Pemoderasi Pengaruh Kepuasan Kerja Terhadap Turnover Intention Pada Karyawan Consignment Pt Matahari Departement Store Tbk. Cabang Bengkulu .Managament Insight: Jurnal IImiah Manajemen. 15(2), 221-231 


\section{PENDAHULUAN}

Karyawan merupakan suatu aset yang sangat penting di dalam suatu perusahaan (Riptiono, 2017). Setiap perusahaan pasti membutuhkan karyawan sebagai tenaga kerja yang menjalankan setiap aktivitas yang ada dalam organisasi tersebut. Tanpa mesin yang canggih, perusahaan masih tetap bisa beroperasi secara manual, namun jika karyawan yang tidak ada, maka perusahaan tersebut tidak dapat beroperasi dengan sempurna (Mobley, 1986). Menurut Cascio (1987) bahwa manusia adalah sumber daya yang sangat penting dalam bidang- bidang industri dan organisasi, oleh karena itu, pengelolaan sumber daya mencakup penyediaan tenaga kerja yang bermutu, mempertahankan kualitas, dan mengendalikan biaya ketenagakerjaan.

Mobley (1986) berpendapat bahwa turnover adalah berhentinya individu dari anggota suatu organisasi dengan disertai pemberian imbalan keuangan oleh organisasi yang bersangkutan. Sedangkan menurut Jung et al, (2012), Turnover intention adalah niat untuk mengundurkan diri dari pekerjaannya saat ini, dan kecenderungan untuk mencari pekerjaan di organisasi lain. Niat turnover mewakili perkiraan pribadi tentang kemungkinan karyawan meninggalkan pekerjaannya dalam waktu dekat (Cho et al., 2009).

Turnover intention dibagi menjadi 2 kategori, yaitu turnover sukarela dan turnover bukan sukarela (Lam et al., 2003). Turnover sukarela adalah keputusan seorang karyawan untuk meninggalkan organisasi. Sedangkan turnover bukan sukarela adalah kepergian karyawan yang diprakarsai oleh atasan (Lam et al.,2003).

Locke (1976) menyatakan bahwa terdapat hubungan yang erat antara kepuasan kerja dengan turnover. Hal tersebut diperkuat oleh teori yang dikemukakan oleh Mobley (1979), dimana ia menyatakan bahwa turnover intention sebagian besar dipengaruhi oleh kepuasan kerja. Kepuasan kerja didefinisikan sebagai keadaan emosi yang senang atau emosi positif yang berasal dari penilaian pekerjaan atau pengalaman kerja seseorang (Lunthas, 2006). Kepuasan kerja merupakan hal yang bersifat individual karena setiap individu akan memiliki tingkat kepuasan yang berbeda-beda. Kepuasan kerja seseorang dapat diukur berdasarkan pekerjaannya sendiri, gaji, promosi, atasan, dan rekan kerja.

Price (1977) melakukan pengembangan model turnover, dimana ia memperoleh bahwa bukan hanya kepuasan kerja yang berpengaruh terhadap turnover, melainkan Perceived Alternatives Opportunity juga mempengaruhi turnover, yang kemudian berefek pada niat untuk keluar. Teori ini diperkuat oleh teori yang dikemukakan oleh Hom \& Griffeth (1991) yang menyatakan bahwa Perceived Alternatives Opportunity berpengaruh terhadap turnover intention.

Perceived Alternatives Opportunity didefiniskan sebagai ketersediaan pekerjaan alternatif di pasar tenaga kerja ekternal (March \& Simon, 1958). Persepsi kesempatan alternatif dianggap dapat memudahkan karyawan untuk bergerak dari satu organisasi ke organisasi yang lainnya (March \& Simon, 1958). Menurut Jansen \& Roodt 
(2014) Perceived Alternatives Opportunity menjadi salah satu faktor yang mempengaruhi Turnover Intention. Teori yang dikemukakan oleh Hom \& Griffeth (2004) menyatakan bahawa Perceived Alternatives Opportunity memoderasi Pengaruh Kepuasan Kerja Terhadap Turnover Intention. Teori tersebut kemudian diperkuat oleh teori yang dikemukakan oleh Carsten \& Spector (1987), yang menyatakan bahwa kepuasan kerja mempengaruhi turnover intention yang dimoderasi oleh Perceived Alternatives Opportunity.

\section{KAJIAN PUSTAKA}

\section{Turnover Intention}

Tett \& Meyer (1993) mendefinisikan turnover intention sebagai keinginan sadar dan terencana yang dilakukan karyawan untuk meninggalkan organisasi. Lee dalam Varshney (2014) menyatakan bahwa turnover intention adalah persepsi subjektif dari aggota organisasi untuk keluar dari pekerjaannya saat ini untuk mencari kesempatan lain, pendapat lain dikemukaan oleh Lacity et al., (Bothma \& Rood, 2013), yang mendefisinikan turnover intention sebagai sejauh mana seorang karyawan berencana untuk meninggalkan organisasi.

\section{Indikator Turnover Intention}

Menurut Michaels \& Spector dalam Lee \& Zhao (2010) ada 3 yang hal yang menjadi indikator turnover intention. Menurut keduanya, yang menjadi indikator turnover intetnion yaitu :

\section{Thinking Of Quitting}

2. Intention To Search For Alternatives

3. Intention To Quit

\section{Kepuasan Kerja}

Robbins \& Judge (2013) mendefinisikan kepuasan kerja sebagai perasaan pisitif tentang suatu pekerjaan yang merupakan hasil evaluasi dari beberapa karakteristik. Sedangkan menurut Kreitner \& Kinichi (2010), kepuasan kerja adalah respon perasaan atau emosional terhadap pekerjaan seseorang. Pendapat lain dikemukakan oleh Lunthas (2011), yang menyatakan bahwa kepuasan kerja adalah sesuatu yang dihasilkan dari penilaian seseorang atas pekerjaan atau pengalaman kerja.

Kepuasan setiap karyawan berbeda satu sama lainnya. Sikap positif terhadap pekerjaan menandakan adanya kepuasan kerja. Sedangkan sikap negatif dan menguntungkan terhadap pekerjaan menandakan adanya ketidakpusan kerja (Lunthas, 2006). 


\section{Dimensi dan Indikator Kepuasan Kerja}

Indikator kepuasan kerja ada 5, yaitu The Work it Self, Pay, Promotions, Supervision, dan work group(Alpahrasy dan Nasution, 2017; Lunthas, 2011).

1. The Work it Self. Pekerjaan yang memberikan kepuasan adalah pekerjaan yang menarik dan menantang, pekerjaan yang tidak membosankan, serta pekerjaan yang dapat membantu pengembangan karir. Indikasi- indikasinya yaitu :
a. Pekerjaan yang menarik
b. Pekerjaan yang menantang
c. Pekerjaan yang tidak membosankan
d. Pekerjaan yang dapat mengembangkan karir

2. Pay. Gaji yang dibayar secara tepat waktu, sesuai dengan pekerjaan yang dilakukan, dan adanya peningkatan pembayaran gaji membuat kepuasan karyawan akan semakin meningkat. Indikasi-indikasinya yaitu :

a. Dibayar secara adil sesuai pekerjaan yang dilakukan

b. Gaji yang diterima tepat waktu

c. Adanya kenaikan gaji

3. Promotions. Promosi berkaitan dengan perkembangan karir, promosi jabatan, dan kenaikan gaji. Indikasi-indikasinya yaitu :

a. Memperoleh kesempatan dalam pengembangan karir

b. Memiliki kesempatan yang sama dalam promosi jabatan

c. Memperoleh kenaikan gaji

4. Supervision. Supervisi merupakan sumber kepuasan kerja lainnya yang cukup penting. Ada 2 gaya pengawasan yang dapat mempengaruhi kepuasan yaitu berpusat pada karyawan dan partisipasi atau pengaruh. Indikasi-indikasinya yaitu:

a. Memeriksa pekerjaan karyawan

b. Atasan memberikan dukungan dan bantuan

c. Hubungan atasan dengan karyawan sangat baik

d. Karyawan memiliki partisipasi penuh dalam pengambilan keputusan

5. Work group. Rekan kerja yang ramah dan kooperatif merupakan sumber kepuasan kerja bagi karyawan. Indikasi-indikasinya yaitu :

a. Rekan kerja yang ramah

b. Menikmati pekerjaaan dengan rekan kerja

c. Saling membutuhkan dan bergantungan

\section{Perceived Alternatives Opportunity}

Perceived alternatives opportunity didefiniskan sebagai kemudahaan yang dirasakan karyawan untuk bergerak (March \& Simon, 1958). Perceived alternatives opportunity juga didefinikan sebagai ketersediaan pekerjaan alternatif di pasar tenaga kerja ekternal (March \& Simon, 1958), umumnya digambarkan sebagai keyakinan individu bahwa mereka dapat memperoleh pekerjaan alternatif (Gerhart, 1990), dan 
dapat menjadi variabel kunci untuk mempengaruhi hubungan antara keterikatan pekerjaan, kepuasasn pembayaran, dan turnover sukarela. Ini berarti bahwa, semakin banyaknya ketersedian pekerjaan diluar organisasi yang karyawan rasakan, maka semakin besar kemudahan bagi karyawan dalam mencari pekerjaan lain (Tosi, 2008).

\section{Indikator Perceived Alternatives Opportunity}

Menurut Gerry Treuren (2013), ada 5 indikator dalam pengukuran Perceived Alternatif Opportunity, diantaranya :

1. Mudah menemukan pekerjaan lain

2. Mudah menemukan pekerjaan yang lebih baik

3. Mudah menemukan pekerjaan yang sama ditempat lain

4. Mengetahui beberapa alternatif pekerjaan lain

5. Memiliki tawaran pekerjaan baru

\section{METODE PENELITIAN}

Jenis penelitian yang digunakan dalam penelitian ini adalah penelitian kuantitatif. Penelitian kuntitatif adalah suatu proses menemukan pengetahuan yang menggunakan data berupa angka sebagai alat menganalisis keterangan mengenai apa yang ingin diketahui (Kasiram, 2008). Desain penelitian yang digunakan dalam penelitian ini, yaitu survei. Menurut Sugiyono (2013), penelitian survei adalah penelitian yang dilakukan dengan menggunakan angket sebagai alat penelitian yang dilakukan pada populasi besar maupun kecil, tetapi data yang dipelajari adalah data dari sampel yang diambil dari populasi tersebut, sehingga ditemukan kejadian relatif, distribusi, dan hubungan antar variabel, sosiologis maupun psikologis.

Penelitian ini menggunakan teknik pengumpulan data dengan teknik kuesioner. Teknik ini memberikan tanggung jawab kepada responden untuk membaca dan menjawab pertanyaan. Pengukuran variabel yang digunakan dalam penelitian ini yaitu pengukuran dengan skala likert. Menurut Sugiyono (2013) skala likert adalah skala yang digunakan untuk mengukur sikap, pendapat, dan persepsi seseorang atau sekelompok orang tentang fenomena sosial.

Populasi dari penelitian ini yaitu seluruh karyawan consignment di PT Matahari Departement Store Tbk cabang Bengkulu, dengan jumlah karyawan consignment yang berada di bawah naungan PT Matahari Departement Store Tbk cabang Bengkulu sebanyak 169 orang, terdiri dari 10 bagian penjualan

Metode pengambilan sampel yang digunakan pada penelitian ini yaitu metode non probability sampling. Salah satu metode Non probability sampling adalah teknik sampling jenuh (sensus). Menurut Sugiyono (2013) metode sampling jenuh (sensus) adalah teknik pengambilan sampel jika semua populasi dijadikan sampel. Maka peneliti menentukan jumlah sampelnya yaitu sebanyak 169 orang. 


\section{Uji Validitas dan Uji Reliabilitas}

\section{Uji Validitas}

Validitas adalah suatu ukuran yang mneunjukkan bahwa variabel yang diukur memang benar- benar variabel yang hendak diteliti oleh peneliti (Cooper \& Schindler, 2006). Validitas dalam penelitian menyatakan derajat ketepatan alat ukur penelitian terhadap isi sebenarnya yang diukur. Ghozali (2009) menyatakan bahwa uji validitas digunakan untuk mengukur sah, atau valid tidaknya suatu kuesioner. Suatu kuesioner dikatakan valid jika pertanyaan pada kuesioner mampu untuk mengungkapkan sesuatu yang akan diukur oleh kuesioner tersebut. koefisien korelasi yang diperoleh $r$ masih harus diuji signifikannya dengan membandingkan dengan $r$ tabel. Kuesioner dikatakan valid jika nilai t hitung $>r$ tabel atau nilai $p<0,05$.

\section{Uji Reliablitas}

Ghozali (2009) menyatakan bahwa reliabilitas adalah alat untuk mengukur sutau kuesioner yang merupakan indikator dari peubah atau konstruk. Suatu kuesioner dikatakan reliabel atau handal jika jawaban seseorang terhadap pernyataan adalah konsisten atau stabil dari waktu ke waktu. Reliabilitas suatu test merujuk pada derajat stabilitas, konsistensi, daya presiksi, dan akurasi. Pengukuran yang memiliki reliabilitas tinggi adalah pengukuran yang dapat menghasilkan data yang reliabel. Indikator pengukuran reliabilitas menurut Sakaran (2000) yang membagi tingkat reliabilitas dengan kriteria sebagai berikut :

- $0,8-1,0=$ reliabilitas baik

- $0,6-0,799=$ reliabilitas diterima

- $<0,7=$ reliabilitas kurang baik

Instrumen dikatakan reliable jika memiliki koefisien alpha yang lebih besar atau sama dengan 0,6 (Sekaran, 2006).

\section{Teknik Analisis Data}

Teknik analisis yang digunakan dalam penelitian ini yaitu Moderated Regression Analysis. Moderated Regression Analysis adalah pendekatan analitik yang mempertahankan integritas sampel dan memberikan dasar untuk mengontrol pengaruh variabel moderator (Ghozali, 2009). Peran dari variabel moderasi tersebut perlu dibuktikan keabsahannya. Tahap- tahap yang perlu dilakukan dalam menggunakan Moderated Regression Analysis (MRA) dapat dilihat dalam Tabel berikut : 
Tabel 1. Tahapan dan Analisis Data

\begin{tabular}{|c|c|}
\hline Tahapan & Analisis \\
\hline Tahapan Pertama & 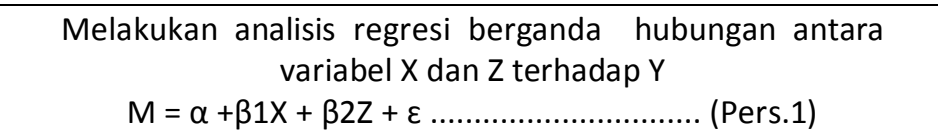 \\
\hline Tahapan Kedua & $\begin{array}{l}\text { Melakukan analisis regresi berganda hubungan antara } \\
\text { variabel } X \text { dan } Z \text { terhadap } Y \text { dan perkalian antara variabel } X \text { dan } Z \\
\text { terhada } Y(Z \text { memoderasi pengaruh } X \text { terhadap } Y) \\
Y=\alpha+\beta 1 X+\beta 2 Z+\beta 1 X . Z+\varepsilon \ldots \ldots \ldots \ldots \ldots \ldots \text { (Pers. } 2)\end{array}$ \\
\hline
\end{tabular}

\section{HASIL dan PEMBAHASAN PENELITIAN}

\section{Pengaruh Kepuasan Kerja (X) dan Perceived Alternatives Opportunity (Z) Terhadap Turnover Intention(Y)}

Koefisien regresi variabel kepuasan kerja sebesar -0,209 yaitu bernilai negatif dan memiliki nilai signifikan $0,000<0,05$. Dapat disimpulkan kepuasan kerja memiliki pengaruh terhadap turnover intention dan pengaruhnya negatif. Kemudian, koefisien regresi variabel Perceived Alternatives Opportunity sebesar 0,209 yaitu bernilai positif dan memiliki nilai signifikan 0,001 <0,05. Dapat disimpulkan Perceived Alternatives Opportunity memiliki pengaruh terhadap turnover intention dan pengaruhnya positif. Hasil pengujian hipotesis pertama (H1) menunjukkan bahwa kepuasan kerja dan Perceived Alternatives Opportunity secara simultan berpengaruh terhadap Turnover Intention. Kepuasan kerja berpengaruh terhadap turnover intention. Hal tersebut dibuktikan dengan $t$ hitung lebih besar dari t tabel $(-7.630>1,98)$ dan nilai signifikan $0,000<0,05$. Dan juga, perceived Alternatives Opportunity berpengaruh terhadap turnover intention. Hal tersebut dibuktikan dengan $t$ hitung lebih besar dari $t$ tabel (3.589 > 1,98) dan nilai signifikan 0,01 < 0,05. Maka dapat disimpulkan bahwa hipotesis pertama ( $\mathrm{H} 1$ ) yang berbunyi : “ kepuasan kerja dan Perceived Alernatives opportunity berpengaruh terhadap turnover intention" di terima. Hasil penelitian ini sejalan dengan teori yang dinyatakan oleh Price (1977) bahwa kepuasan kerja dan Perceived Alternatives Opportunity berpengaruh terhadap turnover intention.

\section{Perceived Alternatives Opportunity(Z) sebagai pemoderasi Pengaruh kepuasan $\operatorname{Kerja}(\mathrm{X})$ Terhadap Turnover Intention( $\mathrm{Y})$}

Koefisien regresi variabel kepuasan kerja sebesar 0,206 yaitu bernilai positif dan memiliki nilai signifikan 0,031 <0,05. Dapat disimpulkan bahwa kepuasan kerja berpengaruh terhadap turnover intention dan pengaruhnya positif. Kemudian, koefisien regresi variabel Perceived Alternatives Opportunity sebesar 1,727 yaitu bernilai positif dan memiliki nilai signifikan $0,000<0,05$. Ini dapat disimpulkan bahwa Perceived Alternatives Opportunity berpengaruh terhadap turnover intention dan pengaruhnya positif. Selanjutkan koefisien regresi variabel perkalian antara kepuasan 
kerja dan Perceived Alternatives Opportunity sebesar 0,024 yaitu bernilai negatif dan memiliki nilai signifikan 0,000 $<0,05$. Ini berarti bahwa variabel perceived alternatives opportunity dapat memoderasi pengaruh kepuasan kerja terhadap turnover intention.

Hasil pengujian Hipotesis kedua (H2) menunjukkan bahwa Perceived Alternatives Opportunity memoderasi pengaruh Kepuasan Kerja Terhadap Turnover Intention. Hal tersebut dibuktikan dengan nilai t hitung lebih besar dari nilai $t$ tabel $(7.630>1,98)$ dan nilai signifikan $0,000<0,05$, maka dapat disimpulkan bahwa hipotesis kedua ( $\mathrm{H} 2$ ) yang berbunyi : "Perceived Alternatives Opportunity memoderasi Pengaruh Kepuasan Kerja Terhadap Turnover Intention" diterima. Hasil penelitian ini sejalan dengan teori yang dikemukakn oleh Hom \& Griffeth (2004) bahwa Perceived Alternatives Opportunity memoderasi pengaruh Kepuasan Kerja Terhadap Turnover Intenton.

\section{KESIMPULAN DAN SARAN}

Berdasarkan hasil penelitian dan pembahasan mengenai Perceived Alternatives Opportunity memoderasi Pengaruh Kepuasan Kerja terhadap Turnover Intention pada karyawan consignment di PT. Matahari Departemen Sore Tbk. Cabang Bengkulu, maka dapat ditarik kesimpulan bahwa Kepuasan kerja dan Perceived Alternatives Opportunity berpengaruh terhadap turnover Intention pada karyawan consignment di PT. Matahari Departemen Store Tbk. Cabang Bengkulu. Kepuasan kerja berpengaruh negatif terhadap turnover intention. Hal ini menujukkan bahwa semakin tinggi tingkat kepuasan kerja karyawan maka keinginannya untuk melakukan turnover intention semakin rendah, dan sebaliknya. Sedangkan Perceived Alternatives Opportunity berpengaruh positif terhadap turnover intention. Hal ini berarti, semakin tinggi persepsi alternatif pekerjaan yang dirasakan karyawan, maka semakin tinggi keinginannya untuk melakukan turnover. Sebaliknya, Perceived Alternatives Opportunity memoderasi pengaruh Kepuasan Kerja terhadap Turnover Intention. Dimana, variabel perceived alternatives opportuntiy ini mengubah hubungan kepuasan kerja terhadap turnover intention yang sebelumnya berpengaruh negatif menjadi positif. Hal ini berarti, dengan alternatif pekerjaan yang tinggi, karyawan dengan tingkat kepuasan yang tinggi akan lebih memilih untuk keluar dari pekerjaannya saat ini.

Hasil dari penelitian ini dapat dijadikan saran atau masukan bagi PT. Matahari Departemen Store Tbk. Cabang Bnegkulu terkait dengan kepuasan kerja, Perceived Alternatives Opportunity, dan Turnover Intention. Bebarapa saran dari hasil penelitian ini, yaitu :Bagi pihak PT. Matahari Departemen Store Tbk, Cabang Bengkulu harus selalu meningkatkan kepuasan kerja karyawannya. Dengan mempertahankan hubungan yang baik dengan sesama rekan kerja dan meningkatkan promosi-promosi jabatan ataupun promosi lainnya. Perusahan bisa membuat suatu program yang dapat mengembangkan karir karyawan, sehingga karyawan merasa lebih puas untuk bekerja karena merasa adanya jaminan dalam pengembangan karir. Dan juga perusahaan dapat 
melakukan kenaikan gaji secara berkala guna meningkatkan rasa komitmen dalam diri karyawan. Sehingga dapat mengurangi tingkat turnover.

2. Untuk menghindari persepsi alternatif pekerjaan lain yang menyebabkan karyawan memilih untuk keluar dari pekerjaannya saat ini dan mencari pekerjaan lain, PT. Matahari Departemen Store Tbk. Cabang Bengkulu harus mampu meningkatkan kenyamanan karyawan dengan memenuhi aspek- aspek yang dapat meningkatkan kepuasan kerja karyawan dengan memberikan fasilitas, seperti promosi jabatan, cuti tahunan, kenaikan gaj, dan hal lainnya yang dapat meningkatkan kepuasan kerja karyawan. 3. PT. Matahari Departemen store Tbk. Cabang Bengkulu juga harus mampu memotivasi atau meyakinkan karyawan bahwa pekerjaannya saat ini jauh lebih baik jika dibandingkan bekerja di tempat lain, dan karyawan akan sangat menyesal jika meninggalkan pekerjaannya saat ini.

\section{DAFTAR PUSTAKA}

Alpahrasy, R., dan Nasution (2017). Pengaruh Motivasi, Kepuasan Kerja, dan Stres Kerja Terhadap Kinerja Karyawan PT. Toyota Agung Automall Bengkulu. Managament Insight: Jurnal IImiah Manajemen. 12(2), 1-12

Carsten, J.M. and Spector, P.E. (1987). unemployment, job satisfaction, and employee turnover: a meta- analytic test of the muchinsky model. Journal of Applied Psycology, 72: 374- 381

Cascio, E.S. 1987. Creative Human Resources Planning and Applications: A Strategic Approach. New Jersey: Prentice-Hall Inc

Cho, S., Johanson, M.M., Guchait, P. (2009). Employees Intent to Leave: A Comparison of Determinants of Intent to Leave Versus Intent to Stay. International Journal of Hospitality Management, 28, 374-381.

Cooper, Donald R., dan Pamela, S. Schindler. (2006). Metode Riset Bisnis. PT Media Global Edukasi. Jakarta

Gerhart, B. (1990). voluntary turnover and alternatives job opportunities. Journal of Applied Psycology, 75: 467- 476

Gerry, Treuren. (2012). The relationship between perceived job alternatives, employee attitudes and leaving intention.

Ghozali, Imam. (2009). Aplikasi Analisis Multivarate dengan Program SPSS. Semarang: UNDIP Hom, P. W., \& Griffeth, R. W.( 2004). Innovative Theory and Empirical Research on Employee Turnover. Mason Street: Greenwich

Hom, P.W. and Griffeth, R.W. (1991) "Structural equations modeling test of a turnover theory: Cross-sectional and longitudinal analyses". Journal of Applied Psychology,76: 350-366

Riptiono, S (2017). Analisis Pengaruh Work Family Conflict dan Family Work Conflict Terhadap Turnover Intention dengan Job Stress Sebagai Mediasi (Studi Pada Karyawan Wanita CV. Tiga Mutiara).Managament Insight: Jurnal IImiah Manajemen. 12(2), 13-22 
Jansen PGW, Roodt G (2014). Conceptualising and measuring work identity : SouthAfrican perspectives and finding. New York: Springer

Jung, Hyo Sun, Hye Hyun Yoon \& Young Joong Kim (2012): Effects of culinary employees' role stress on burnout and turnover intention in hotel industry: moderating effects on employees' tenure, The Service Industries Journal, 32:13, 2145-2165

Kasiram, Moh. (2008). Metodologi Penelitian. Malang: UIN- Malang Pers

Kreitner, R., dan Kinichi, Angelo. . (2010). Organizational Behavior. Ninth Edition. New York McGraw - Hill.

Lacity, M.C., Lyer, V.V., \& Rudramuniyaiah, P.S. (2008). Turnover intentions of Indian IS professionals. Information Systems Frontiers on Outsourcing, 10, 225-241. http:// dx.doi.org/10.1007/s10796-007-9062-3. Intention Scale. Journal of Human Resource Management, 11 (1), 1-12

Lam, T., Pine, R., Baum, T. (2003). Subjective Norms Effects on Job Satisfaction. Annals of Tourism Research, 30 (1), 160-177.

Lee, H., dan Zhao (2010). A Study On Factors Affecting Turnover Intention of Hotel Empolyees. Asian Economic and Financial Review, 2(7), 866- 875

Luthans, F. (2006). Organizational behavior International Edition. new York: McGrawHills

Luthans, F. (2011). Organizational Behavior. 11th edition. New York Mc Graw Hill.

Locke E.A. (1976). "The nature and causes of job satisfaction". in M.D. Dunnette (ed). Handbook of Industrial and Organizational Psyvhology. Chicago : Rand Mcnally

March JG, Simon HA (1958). Organizations. New York : Jhon Wiley and Sons

Michaels, C.E. and P.E. Spector (1982) "Causes of Employee Turnover: A Test of the Mobley, Griffeth, Hand and Meglino Model" Journal of Applied Psychology Vol.67, No.1, pp. 53-59.

Mobley, W. H. (1986). Pergantian Karyawan: Sebab, Akibat dan Pengendaliannya. Terjemahan. Jakarta: PT Pustaka Binaman Pressindo.

Mobley, W. H., Griffeth, R.W., Hand, H.H. and Meglino, B.M. (1979). "Review and conceptual analysis of the employee turnover process". Psychological Bulletin, 86: 493- 522

Price, J.L. (1977). The Study of turnover. Ames, IO: The lowa state University Press

Robbins, S. P. d. J., Timothy A. . (2013). Organizational Behavior, 15th

Sekaran, Uma. 2000. Research Methods for business: A Skill Building Approach. Singapore: John Wiley \& Sons, Inc.

Sugiyono. 2013. Metode Penelitian Pendidikan Pendekatan Kuantitatif, Kualitatif, dan R\&D. Bandung: Alfabeta

Tett, R. P., dan Mayer, J.P, . (1993). Job Satisfaction, Organizational Commitment, Turnover Intention, And Turnover: Path Analyses Based On Metaanalytic Findings. Personnel Psychology, 46, 259-293. 
Tosi HI (2008). Theories of organizations. Los Angeles : Sage Publications

Varshney, D. (2014). Impact of Self - Concept on Turnover Intention: An Empirical Study. American International Journal of Contemporary Research, 4 (10), 87 -96. 